\title{
Rhinacanthus nasutus "Tea" Infusions and the Medicinal Benefits of the Constituent Phytochemicals
}

\author{
James Michael Brimson 1,2®, Mani Iyer Prasanth 1,2, Dicson Sheeja Malar 1,2, \\ Sirikalaya Brimson ${ }^{3}$ and Tewin Tencomnao ${ }^{1,2, *}$ \\ 1 Age-Related Inflammation and Degeneration Research Unit, Chulalongkorn University, Bangkok 10330, \\ Thailand; james.b@chula.ac.th (J.M.B.); Prasanth.I@chula.ac.th (M.I.P.); Sheeja.M@chula.ac.th (D.S.M.) \\ 2 Department of Clinical Chemistry, Faculty of Allied Health Sciences, Chulalongkorn University, \\ Bangkok 10330, Thailand \\ 3 Department of Clinical Microscopy, Faculty of Allied Health Sciences, Chulalongkorn University, \\ Bangkok 10330, Thailand; Sirikalaya.J@chula.ac.th \\ * Correspondence: Tewin.t@chula.ac.th; Tel.: +662-218-1533
}

Received: 20 October 2020; Accepted: 3 December 2020; Published: 9 December 2020

\begin{abstract}
Rhinacanthus nasutus (L.) Kurz (Acanthaceae) $(R n)$ is an herbaceous shrub native to Thailand and much of South and Southeast Asia. It has several synonyms and local or common names. The root of $R n$ is used in Thai traditional medicine to treat snake bites, and the roots and/or leaves can be made into a balm and applied to the skin for the treatment of skin infections such as ringworm, or they may be brewed to form an infusion for the treatment of inflammatory disorders. $R n$ leaves are available to the public for purchase in the form of "tea bags" as a natural herbal remedy for a long list of disorders, including diabetes, skin diseases (antifungal, ringworm, eczema, scurf, herpes), gastritis, raised blood pressure, improved blood circulation, early-stage tuberculosis antitumor activity, and as an antipyretic. There have been many studies investigating the roles of $R n$ or compounds isolated from the herb regarding diseases such as Alzheimer's and other neurodegenerative diseases, cancer, diabetes and infection with bacteria, fungi or viruses. There have, however, been no clinical trials to confirm the efficacy of $R n$ in the treatment of any of these disorders, and the safety of these teas over long periods of consumption has never been tested. This review assesses the recent research into the role of $R n$ and its constituent compounds in a range of diseases.
\end{abstract}

Keywords: cancer; neurodegenerative disease; diabetes; infectious disease; natural products; phytochemicals; snake jasmine

\section{Introduction}

Rhinacanthus genus comprising of about 25 species belongs to the family Acanthaceae and distributed throughout tropical and subtropical regions [1]. Rhinacanthus nasutus (Rn), commonly referred to as snake jasmine because of the shape of its flower, and is a native of Southeast Asia. The plant is also referred to by the names (as well as others (Table 1)) Rhinacanthus rottlerianus Nees and Justicia rottleriana Wall. It is a small, slender shrub growing to a height of about 0.6 to $1.2 \mathrm{~m}$ [2]. It is a woody based plant with sparsely branched club-shaped fruit and four seeds. The whole plant is widely used in traditional medicinal practices for the treatment of diverse disease conditions. Medicinal preparations of the plant in the form of decoctions and herbal tea have been given internally to the people for the treatment of hepatitis, diabetes, hypertension, while the external application in the form of paste has been used by the people who suffer from psoriasis, eczema, ringworm as well as inflammation. Traditionally seeds, roots and leaves of the plant have been used against scabies, eczema and various skin conditions. Leaves are used for prickly heat as well as scurf, and roots are being 
boiled along with milk and used as an aphrodisiac. A decoction of roots is used as an antidote for snake bites. Stem and leaves of the plant are used to treat pulmonary tuberculosis and high blood pressure [3].

Several reports have revealed the folklore and traditional medicinal practices using $R n$ ranging from antioxidant, antimicrobial to anticancer and neuroprotectant. The rhinacanthin-rich leaf extract has been reported to have antimicrobial activity against $S$. mutans, S. epidermidis, P. acnes and S. aureus [4]. Traditional usage of $R n$ in the treatment of skin diseases caused by fungi has been reported, showing that the leaf extract has fungicidal activity by acting on the cell wall causing its degeneration and death [5]. The leaf extract of the plant also showed significant larvicidal activity against Culex quinquefasciatus, Anopheles stephensi, Aedes aegypti and prevented the emergence of larvae to adults [6,7]. Further, a formulation containing root extract of the plant has also been prepared for the control of mosquito vectors [8]. Methanolic extract of $R n$ was found to exhibit significant antioxidant activity in cell-free in vitro studies as well could ameliorate oxidative stress and improve the antioxidant status in experimental rats $[9,10]$. Additionally, methanol extract of the root was reported to exhibit a cytotoxic effect against oral squamous cell carcinoma cells and promyelocytic leukemia cells while showing lower-level cytotoxicity to normal cells [11]. Ethanolic extract of the plant was shown to exhibit hepatoprotective activity against aflatoxin B1 induced toxicity in Wistar rats by enhancing the glutathione level and modulating the activity of serum enzymes [12]. In addition, the root extract inhibited lipopolysaccharides (LPS)-induced inflammation by reducing the level of nitric oxide (NO) in RAW264.7 macrophage cells [11]. Further, $R n$ root extract has also been reported to have a neuroprotective effect against hypoxia as well as glutamate-induced cell death in HT22 cells by bringing back the redox homeostasis [13,14].

Bibliographical analysis of the publications (original research articles) related to $R n$ shows a significant increase in publications from the late 2000s onwards with $11 R n$ related articles published in 2009, 70 articles in 2015 and 62 so far in 2020. These articles break down into the following subject areas; pharmacology and toxicology $(19 \%)$, biochemistry, genetics and molecular biology $(17 \%)$, agricultural and biological sciences $(17 \%)$, chemistry $(14 \%)$, medicine $(13 \%)$, immunology $(4 \%)$ and others $(16 \%)$ (data obtained from SCOPUS).

With the recent increase of publications related to $R n$ in mind, this review aims to cover the advances and research into $R n$ over the last decade in the fields of neurodegeneration, cancer, diabetes, as well as $R n^{\prime}$ s proprieties as an antimicrobial, antiviral and antifungal agent, and assess whether there is enough evidence to warrant the use of $R n$ or compounds isolated from $R n$ in human trails. All plants described in this manuscript have had their names checked at The Plant List [15]. 
Table 1. List of common/regional names of Rhinacanthus nasutus (L.) Kurz.

Synonyms

Rhinacanthus nasutus (L.) Kurz

Rhinacanthus communis Nees

Rhinacanthus osmospermus Bojer ex Nees

Justicia dichotoma Rottler*

Justicia nasuta L.

Justicia macilenta E. Mey. *

Justicia rottleriana Wall. *

Justicia silvatica Nees *

Justicia sylvatica Vahl *

Pseuderanthemum connatum Lindau

Dianthera paniculata Lour.

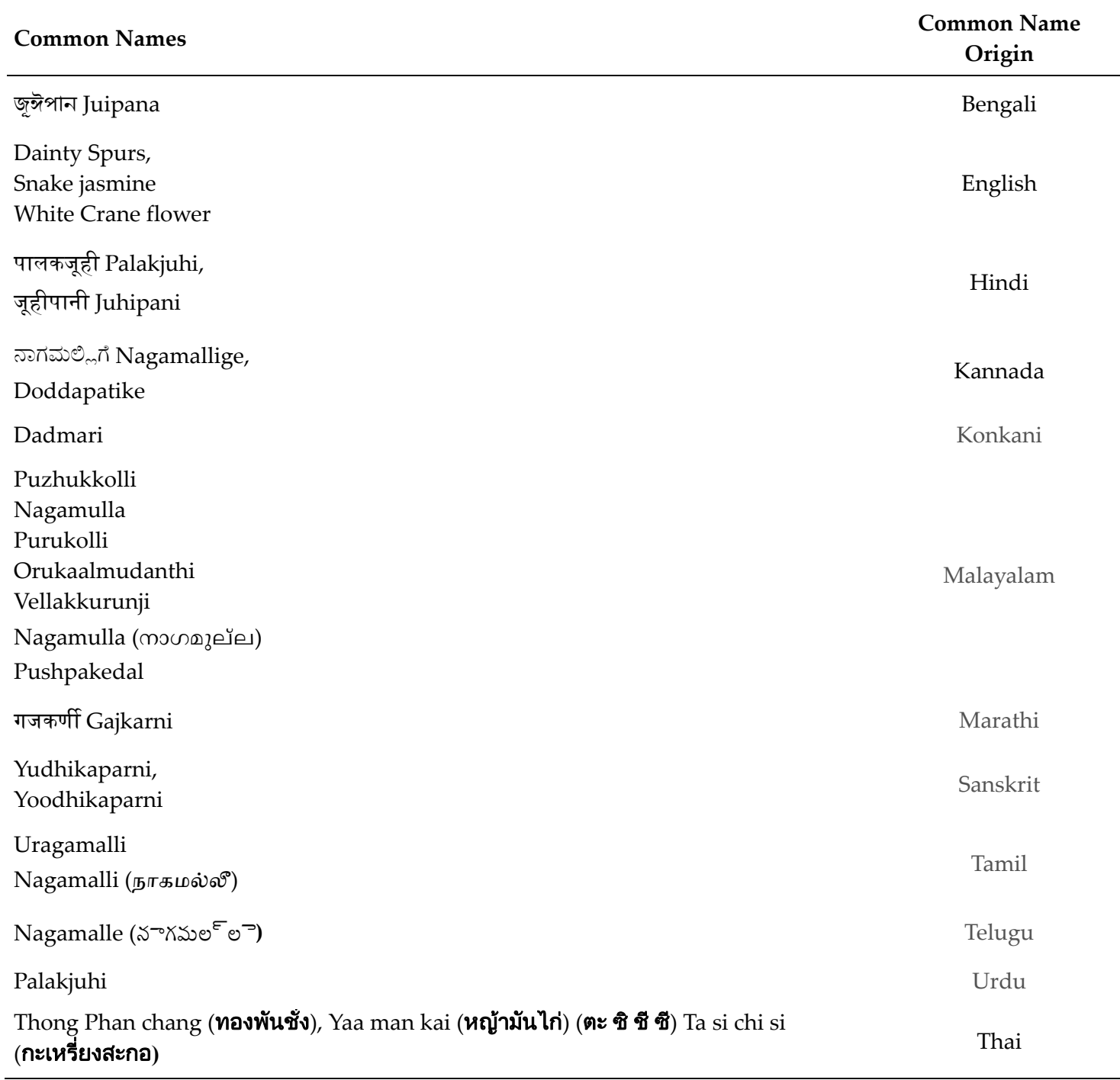

* Name is unresolved, but some data suggest that it is synonymous with Rhinacanthus nasutus (L.) Kurz (Rn) (checked via the plant list [15]. 


\section{Phytochemicals Found in Rhinacanthus nasutus}

$R n$ has been identified as an important medicinal plant due to its medicinal properties for various disease conditions. This has led to the characterizing of the active ingredients responsible for exhibiting these medicinal properties (Table 2). Kodama et al. 1993 has reported the isolation of a naphthopyran derivative 3,4-dihydro-3,3-dimethyl-2H-naphtho[2,3-b]pyran-5,10-dione which also possess antifungal activity [16]. Several phytochemicals including $\beta$-amyrin, glutinol, lupeol, stimasterol, sitosterol, umbelliferone, 2-methylanthraquinone, wogonin, oroxylin A, (+)-praeruptorin, p-hydroxy benzaldehyde, methyl vanillate, syringaldehyde, Dehydro- $\alpha$-lapachone and novel compounds rhinacanthin A-D, G-Q, (RnA-D and RnG-Q) rhinacanthone, 4-acetonyl-3,5-dimethoxy-p-quinol have been isolated by $\mathrm{Wu}$ et al. 1998 from the roots, stem and leaves of $R n$ [17-19]. Rhinacanthin $\mathrm{S}$ $(\mathrm{RnS})$ and RnA isolated from the leaves of $R n$ showed acetylcholinesterase inhibitory activity and cytotoxicity, respectively [20]. RnC has also been found to attenuate renal oxidative stress and protect against streptozotocin-nicotinamide induced diabetic nephropathy in rats [21]. Based on the antiviral property of the plant, several research groups have succeeded in isolating and examining the activity of phytochemicals from the roots and aerial parts of R. nasutus. Sendl et al. 1996 has reported the isolation of two naphthoquinones, $\mathrm{RnC}$ and $\mathrm{RnD}$, from the whole plant and their antiviral activity against human cytomegalovirus [22]. The lignans Rhinacanthin E and F ( $\mathrm{nnE}$ and RnF) isolated from the aerial part of the plant have been reported to have significant activity against the influenza virus under in vitro conditions [23]. An antiviral study by Ngoc et al. 2019 with a novel naphthoquinone analog rhinacasutone and seven other known compounds like rhinacanthone, $\mathrm{RnC}, \mathrm{RnD}, \mathrm{RnN}, \mathrm{RnQ}$ and $\mathrm{RnE}$ and heliobuphthalmin indicated that $\mathrm{RnC}, \mathrm{RnD}, \mathrm{RnN}$ and $\mathrm{RnQ}$ exhibit significant antiviral activity against influenza virus A/PR/8/34 (PR8), Anti-Human Rhinovirus 1B (HRV1B), and Coxsackievirus B3 (CVB3) [24]. Kwak et al. 2018 has isolated trans O-coumaric acid, 2,4-dihydroxycinnamic acid, 3,4-dimethoxyphenyl-O- $\beta$-D-glucopyranoside, p-hydroxy phenethyl trans-ferulate, 2,3-bis[(4-hydroxy-3,5-dimethoxyphenyl)methyl]-1,4-butanediol,8,8'-bisdihydrosiringenin glucoside, dehydrodiconiferyl alcohol-4- $\beta$-D-glucoside and (-)-dehydrodiconiferyl alcohol from the aerial parts of the plant. Among which, 2,3-bis[(4-hydroxy-3,5-dimethoxyphenyl)methyl]-1,4-butanediol and $8,8^{\prime}$-bisdihydrosiringenin glucoside were found to have significant neuraminidase inhibitory activity [25]. 
Table 2. Structures and activities of compounds found specifically in Rhinacanthus nasutus extracts.

\begin{tabular}{|c|c|c|}
\hline Name & Structure & Reported Activities \\
\hline 2-Hydroxy-1,4-naphthoquinone & & $\begin{array}{l}\text { An interconversion of pyridine nucleotides to combat the effects of oxidative stress } \\
\qquad[26]\end{array}$ \\
\hline 3,4-dihydro-3,3-dimethyl-2H-naphtho[2,3-b] pyran-5,10-dione & & Antitumor activity [27] \\
\hline Rhinacanthin A & & Inhibited the growth of S. aureus with an inhibition zone of $16 \mathrm{~mm}$ ( $25 \mathrm{~mm}$ disk) [28] \\
\hline Rhinacanthin B & & Inhibition of cytochrome enzymes CYP6AA3 and CYP6P7 in vitro [29] \\
\hline Rhinacanthin C & & $\begin{array}{l}\text { Prevented A } \beta \text {-induced toxicity in rat hippocampal neurons and attenuated } \\
\text { lipopolysaccharides (LPS)-activated nitric oxide (NO) production, inducible NO } \\
\text { synthase (iNOS) expression, and nuclear factor kappa-light-chain-enhancer of } \\
\text { activated B cells (NF-kB) signaling in rat glia [30] } \\
\text {;Exhibited neuroprotective effect by reducing cleaved caspase-3- and } \\
\text { caspase-9a-related apoptosis and anti-inflammatory effect by decreasing High } \\
\text { mobility group box 1 (HMGB-1) mRNA and protein expression [31]; } \\
\text { Inhibits cholangiocarcinoma cell migration and invasion by decreasing matrix } \\
\text { metalloproteinase-2 (MMP-2), Urokinase-Type Plasminogen Activator (uPA), focal } \\
\text { adhesion kinase (FAK) and mitogen-activated protein kinase (MAPK) pathways, } \\
\text { along with inhibition of cell migration and antiproliferative effects [32] }\end{array}$ \\
\hline Rhinacanthin D & & $\begin{array}{l}\text { Inhibitory activity against cytomegalovirus [22]; } \\
\text { antiviral activities against influenza virus A/PR/8/34 (PR8), Anti-Human Rhinovirus } \\
\text { 1B (HRV1B), and Coxsackievirus B3 (CVB3)-infected Vero cells [24] }\end{array}$ \\
\hline
\end{tabular}


Table 2. Cont.

\begin{tabular}{|c|c|c|}
\hline Name & Structure & Reported Activities \\
\hline Rhinacanthin E & & Antiviral activity against influenza virus type A [23] \\
\hline Rhinacanthin F & & Antiviral activity against influenza virus type A [30] \\
\hline Rhinacanthin $G$ & & Inhibition of cytochrome enzyme CYP6P7 in vitro [29] \\
\hline Rhinacanthin M & & $\begin{array}{l}\text { Inhibition of cancer cell lines } \mathrm{KB}, \mathrm{HeLa} \text {, and } \mathrm{HepG}_{2} \text { with } \mathrm{IC}_{50} \text { values of } 1.5,3.0 \text { and } \\
\qquad 4.6 \mu \mathrm{M} \text {, respectively [33] }\end{array}$ \\
\hline Rhinacanthin $N$ & & $\begin{array}{c}\text { Rhinacanthin-N caused G2/M arrest of HeLaS3 cells after } 24 \mathrm{~h} \text { incubation and } \\
\text { increased the proportion of sub-G1 hypodiploid cells, apoptotic cells [34]; } \\
\text { Antimetastatic activity as it inhibited the metastatic pulmonary colonization of the } \\
\text { melanoma cells in C57BL/6 male mice [35]; } \\
\text { Antiproliferative activity against HeLaS3 cells and suppressed tumor growth } \\
\text { in vivo [36] }\end{array}$ \\
\hline
\end{tabular}


Table 2. Cont.

\begin{tabular}{|c|c|c|}
\hline Name & Structure & Reported Activities \\
\hline Rhinacanthin $O$ & & Unknown activities \\
\hline Rhinacanthin $Q$ & & $\begin{array}{l}\text { Induction of apoptosis in tumor cells that may be associated with the activation of } \\
\text { the caspase-3 pathway [34]; } \\
\text { Antiviral activities against PR8, HRV1B, and CVB3-infected Vero cells [24] }\end{array}$ \\
\hline Rhinacasutone & & Unknown activities \\
\hline Heliobuphthalmin & & $\begin{array}{c}\text { Strong inducer of apoptosis in HuH-7 cells [37]; } \\
\text { High antineoplasic activities against the classical (multi-drug-resistant) MDR } \\
\text { subline derived from gastric carcinoma [38] }\end{array}$ \\
\hline Rhinacanthone & & $\begin{array}{l}\text { Rhinacanthone-induced apoptosis in HeLa cells is mediated primarily through the } \\
\text { mitochondrial-dependent signaling pathway as it inhibited proliferation of HeLa } \\
\text { cells along with chromatin condensation, internucleosomal DNA fragmentation, } \\
\text { increase in the proportion of sub G(1) apoptotic cells, and externalization of } \\
\text { annexin-V. Increase in the level of Bax and a decrease in the level of Bcl-2 and } \\
\text { activation of caspase } 3 \text { and 9 [39]; } \\
\text { Inhibited tumor cell growth in Dalton's ascitic lymphoma (DAL) in Swiss albino } \\
\text { mice [40] }\end{array}$ \\
\hline
\end{tabular}




\section{Rhinacanthus nasutus and Neurodegenerative Diseases}

Neurodegenerative diseases pose a significant health issue since the average ages of the world's populations are increasing, and there are more older generations alive than at any time in previous decades. Age brings numerous health problems, including neurodegenerative diseases such as Alzheimer's disease, Parkinson's disease, multiple sclerosis, and amyotrophic lateral sclerosis. There are currently 44 million people living with Alzheimer's, 7 million living with Parkinson's disease worldwide [41,42]. With the rise in population and life expectancy around the world, these numbers are predicted to rise to 76 million by 2030 and 135 million by 2050 for Alzheimer's disease, and up to 20 million by 2050 for Parkinson's diseases [42,43].

Treatments for neurodegenerative diseases fall into three general categories; preventative, restorative, and regenerative. The restorative category covers most drugs available for the treatment of neurodegenerative diseases, such as levodopa for Parkinson's and acetylcholinesterase inhibitors for Alzheimer's disease. These drugs are often prescribed after symptoms have begun to show, long after the initial neurodegeneration has taken place, with the aim of replacing neurotransmitters that are lost from the neurodegeneration. These treatments often only improve the symptoms but do not slow or reverse the progression of the disease in any way. Regenerative treatments are the holy grail of neurodegenerative diseases, drugs that stimulate the growth of new neurons to replace those that have been lost, thus restoring function or the implantation of stem cells that would grow and differentiate into the desired neuronal cells to replace those that were lost. For now, despite advances in the field, these kinds of drugs and therapies are still a long way from being brought to clinical trials [44]. Preventative treatments tend to cover dietary and behavioral changes that reduce the risk of neurodegenerative diseases. Examples of preventative measures that can reduce the relative risk of developing Alzheimer's include not smoking, maintaining an active lifestyle, maintaining a healthy weight, and treating diseases such as depression and diabetes.

Herbal remedies and traditional medicines for the treatment of cognitive decline have been used for centuries, and many have been shown to have positive effects on neurons in a laboratory setting, such as Curcuma longa [45], Mucuna pruriens [46], and Bacopa monnieri [47]. Rn is lesser known for its neuroprotective effects; however, there has been much research suggesting that it could be beneficial in the prevention and treatment of neurodegenerative disease [48]. Previous work from our laboratory has shown that $R n$ has potent antioxidant effects in cultured neuronal cell lines subjected to hypoxia [13] and that $R n$ can counteract the cytotoxic effects of glutamate and amyloid- $\beta(\mathrm{A} \beta)$ [14]. We, therefore, hypothesized a reactive oxygen species inhibiting model (Figure 1) that could explain the protective effects of $R n$ [49]. Many other studies have shown that $R n$ possesses potent antioxidant effects, with the crude leaf extract showing similar free radical scavenging properties to the standard Trolox and prevent reactive oxygen species (ROS) induced hemolysis of red blood cells [50,51]. Furthermore, active compounds such as $\mathrm{RnC}, \mathrm{RnD}$ and $\mathrm{RnN}$ being potent superoxide scavengers [52].

There is increasing evidence to suggest that neurodegenerative disease is not restricted to a neurological component; rather, there is a strong interaction with immunological mechanisms in the central nervous system (CNS). In particular, diseases such as Alzheimer's [53], Parkinson's [54], multiple sclerosis [55], and ALS [56] have evidence for immunological components. Recent work investigating the neuroprotective effects of $\mathrm{RnC}$ (one of the major active compounds found in $\mathrm{Rn}$ ) has shown that RnC is able to attenuate neuroinflammation brought on by LPS, A $\beta$, and interferon- $\gamma$ in BV-2 and primary rat glial cells [30]. In particular, this study showed that RnC was able to reduce the release of tumor necrosis factor alpha (TNF- $\alpha$ ) and interleukin-6 (IL-6) from BV-2 cells in response to LPS, A $\beta$, and interferon- $\gamma$, as well as reducing NO production and inducible NO synthase (iNOS), IL-1 $\beta$, C-C Motif Chemokine Ligand 2 (CCL-2), and CCL-5 mRNA levels in primary rat microglial cells. Furthermore, the Chuang et al. 2018 study showed that RnC could prevent damage to primary rat neurons caused by $\mathrm{A} \beta$ suggesting that RnC may be a potential in Alzheimer's disease treatment. The findings from this study are in line with other studies investigating $\mathrm{RnC}$ on neuroinflammation [31]. The Chang et al. 2016 study showed that RnC could prevent increases in IL-1 $\beta$, IL-6, and TNF- $\alpha$ 
mRNA expression in animals subjected to subarachnoid hemorrhage. This study suggests that RnC may be of benefit to patients who have suffered from delayed ischemic neurologic deficit following an aneurysm by preventing neuroinflammation, and could explain the neuroprotective effects of $R n$ seen in cultured HT-22 cells that were exposed to hypoxic, low glucose conditions and then reperfused with oxygen and glucose [13]. The neuroprotective effects of $R n$ could further be explained by the finding that RnS has acetylcholinesterase activity [20].

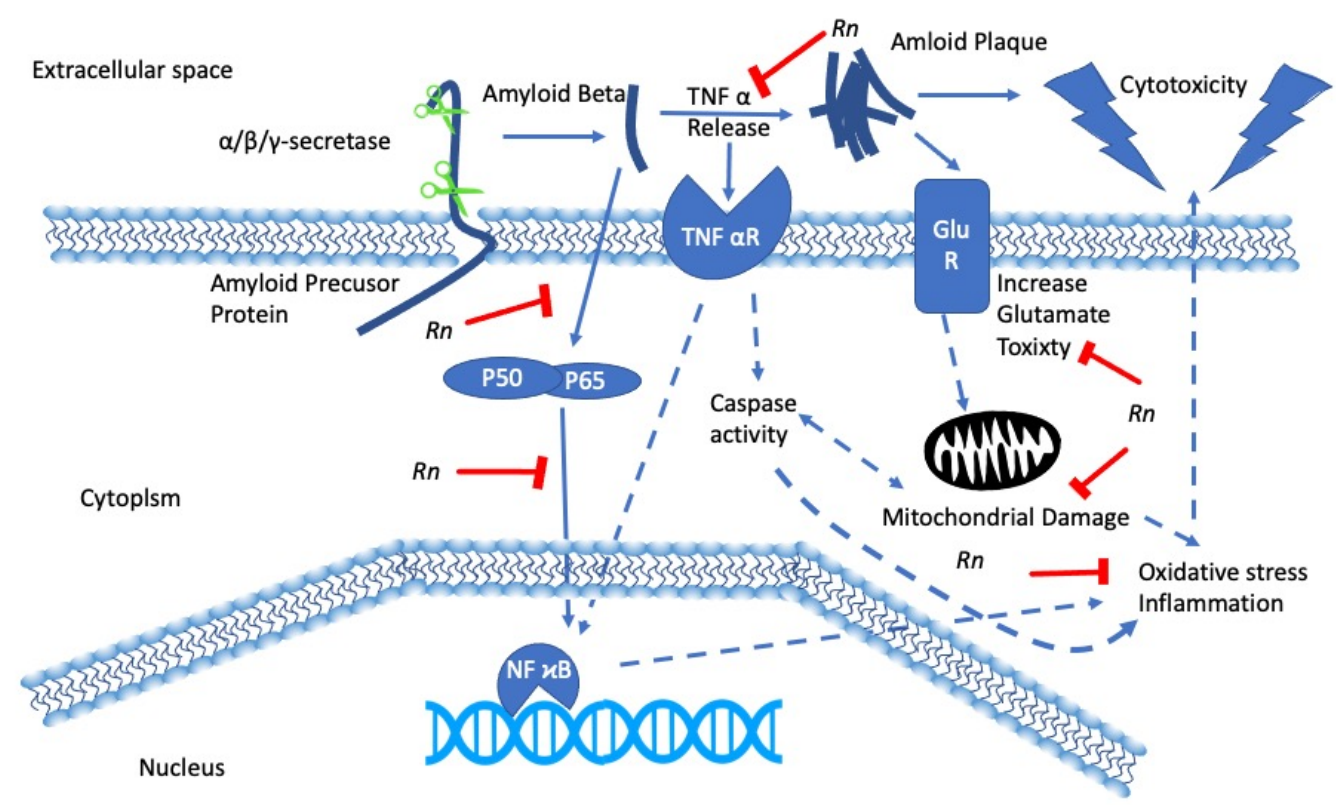

Figure 1. Rhinacanthus nasutus ( $R n)$ and its protective effects in pathways involved in neurodegenerative diseases. $R n$ inhibits tumor necrosis factor alpha $(\mathrm{TNF} \alpha)$ release thus preventing its interaction with the TNF $\alpha$ receptor $(\mathrm{TNF} \alpha \mathrm{R})$. $R n$ also prevents nuclear factor kappa-light-chain-enhancer of activated $\mathrm{B}$ cells (NF-kB) activation, which in turn leads a reduction in oxidative stress.

Altogether, these studies have shown that $R n$ has neuroprotective properties, with potential for the treatment of Alzheimer's and aneurysm patients. The crude extract or its active components have both shown potential for reducing neuroinflammation and providing protection against reperfusion injury.

\section{Rhinacanthus nasutus and Cancer}

Cancer is the term given to a group of diseases that involve abnormal cell growth, with the potential to spread and invade other parts of the body. The 2014 World Health Organization statistics show that there were approximately 18 million new cases and 9 million deaths worldwide.

In normal healthy cells, there are signals that prevent programmed cell death (apoptosis). There are also signals that lead to apoptosis, for example, when a cell is damaged or has reached the end of its lifespan. There are two classes of genes, which under the right circumstance can cause cancers. The first group is the oncogenes, with roles in the promotion of cell division and cell survival. Well-studied examples include the GTPase Ras [57] tyrosine kinase receptors such as epidermal growth factor receptor (EGFR) [58] and transcription factors such as the C-Myc gene [59]. The second class of genes that can lead to cancers are known as tumor suppressor genes. A typical example would be $p 53$, which is mutated in 50\% of human tumors [60].

The principal treatment methods are a combination of surgery, chemotherapy, and radiotherapy. The latter two do not specifically target cancer cells. Instead, any fast proliferating cell, resulting in several undesirable side effects. Ideal cancer treatment would target a specific property of a cancer cell, preventing its growth and inducing apoptosis without harming healthy cells. 
There have been several studies investigating the effects of $R n$ and its constituent compounds on tumor cell growth. The early studies showed that the crude extracts from either the leaves or the roots and some of the extracted compounds could prevent the growth of tumor cell lines (Table 3) such as KB, HEP-2, MCF-7, HepG2, HeLa, SiHa, C-32, LLC, Colon-26, P-388, A-549, HT-29, HL60 and Vero $[17,38,61]$. Rhinacanthone isolated from the roots inhibited the proliferation of HeLa cells and induced apoptosis via the mitochondrial dependent signaling mechanism [39]. RnC displayed potent cytotoxic and antimetastatic activity against cholangiocarcinoma cells (KKU-M156) by inhibiting invasion regulating focal adhesion kinase (FAK) and interfering with mitogen-activated protein kinase (MAPK) pathway [32]. RnA, isolated from the leaves of $R n$, was found to be cytotoxic to MCF7 breast cancer cells (50\% inhibition concertation $\left(\mathrm{IC}_{50}\right)$ value of $\left.8.79 \mu \mathrm{M}\right)$, and $\mathrm{RnN}$ was cytotoxic in NCI-H187 cell line $\left(\mathrm{IC}_{50}\right.$ value of $\left.2.24 \mu \mathrm{M}\right)$ and Vero cells $\left(\mathrm{IC}_{50}\right.$ value of $\left.3.00 \mu \mathrm{M}\right)$ [20].

Table 3. $\mathrm{IC}_{50}$ values for various extracts and isolated compounds from $\mathrm{R} n$ in a range of cancer cell lines. Data extracted from Wu et al. 1998 [17], Siripong et al. 2006 [61] and Siripong et al. 2009 [39].

\begin{tabular}{|c|c|c|c|c|c|c|c|c|c|c|}
\hline $\begin{array}{l}\text { Cell } \\
\text { Line }\end{array}$ & $\begin{array}{c}\text { Chloroform } \\
\text { Extract } \\
\mu \mathrm{g} / \mathrm{mL}\end{array}$ & $\begin{array}{l}\text { Methanol } \\
\text { Extract } \\
\mu \mathrm{g} / \mathrm{mL}\end{array}$ & $\begin{array}{r}\mathrm{RnC} \\
\mu \mathrm{M}\end{array}$ & $\begin{array}{c}\mathrm{RnD} \\
\mu \mathrm{M}\end{array}$ & $\begin{array}{c}\mathrm{RnG} \\
\mu \mathrm{M}\end{array}$ & $\begin{array}{c}\mathrm{RnO} \\
\mu \mathrm{M}\end{array}$ & $\begin{array}{c}\mathrm{RnM} \\
\mu \mathrm{M}\end{array}$ & $\begin{array}{c}\mathrm{RnN} \\
\mu \mathrm{M}\end{array}$ & $\begin{array}{c}\mathrm{RnQ} \\
\mu \mathrm{M}\end{array}$ & $\begin{array}{c}\text { Rhinacanthone } \\
\mu \mathrm{M}\end{array}$ \\
\hline $\mathrm{KB}$ & 0.55 & 3.9 & 0.46 & 0.47 & 4.7 & 5.5 & 2.6 & 0.33 & 1.4 & 3.8 \\
\hline Hep-2 & 0.3 & 4.0 & 0.8 & 7.6 & 3.3 & 3.7 & 6.1 & 1.2 & 3.6 & 4.4 \\
\hline MCF-7 & 0.8 & 20.0 & 0.88 & 14.7 & 8.7 & 8.1 & 8.9 & 2.6 & 10.6 & 4.9 \\
\hline HepG2 & 0.95 & 8.5 & 0.41 & 1.9 & 1.2 & 6.5 & 3.8 & 0.37 & 3.0 & 4.9 \\
\hline $\mathrm{HeLa}$ & 0.39 & 4.4 & 0.29 & 0.49 & 4.7 & 6.1 & 4.3 & 0.87 & 3.8 & 4.2 \\
\hline $\mathrm{SiHa}$ & 1.5 & 21.0 & 0.49 & 6.6 & 18.8 & 7.4 & 39.1 & 3.9 & 6.1 & 2.9 \\
\hline C-32 & 5.0 & 30.0 & 9.8 & 14.7 & 16.4 & 30.7 & 37.0 & 39.1 & 8.4 & 2.1 \\
\hline LLC & 1.8 & 40 & 0.98 & 6.1 & 6.1 & 8.2 & 54.4 & 5.4 & 8.3 & 2.9 \\
\hline Colon-26 & 0.3 & 5.0 & 0.44 & 2.3 & 1.5 & 6.6 & 5.4 & 1.1 & 1.1 & 3.4 \\
\hline P-388 & 0.3 & 7 & 1.5 & 9.3 & 3.3 & 8.9 & 8.1 & 3.7 & 10.3 & 4.4 \\
\hline Vero & 0.2 & 2.5 & 11.0 & 34.3 & 16.4 & 12.3 & 36.1 & 12.7 & 41.1 & 4.2 \\
\hline
\end{tabular}

\section{Rhinacanthus nasutus and Diabetes}

Worldwide, diabetes is regarded as one of the leading causes of death. According to the international diabetes federation, 463 million adults are living with the disease, and the figure is expected to increase by 700 million in 2045 [62]. Diabetes is a cluster of metabolic diseases resulting in a hyperglycemic condition. The increase in blood sugar level may result from impaired insulin secretion and action along with disruption in the normal metabolism of carbohydrates, proteins and lipids, leading to detrimental health effects. Diabetes is also characterized by a rise in fatty acids and triglycerides along with a decline of high-density lipoprotein cholesterol (HDL-C), leading to the deposition of fat and obesity [63]. Hyperglycemia can also increase the level of oxidative stress inside the system, which also contributes to the prevalence of diabetes [10]. Diabetic patients are also prone to suffer from other mild to severe complications like diabetic retinopathy, diabetic nephropathy, diabetic neuropathy, myocardial infarction and multiple organ failure.

Among the several antidiabetic mechanisms, inhibition of $\alpha$-glucosidase has been reported as the main event in exhibiting the effect, and $\alpha$-glucosidase inhibitors have been widely prescribed for treating type II diabetes. $\alpha$-glucosidase is involved in the conversion of starch and disaccharides to simple sugars, thereby increasing the glucose level in circulation [64]. In vitro studies have demonstrated that a rhinacanthin rich extract and its active constituent $\mathrm{RnC}$ exhibit noncompetitive inhibition against the $\alpha$-glucosidase enzyme. In silico studies also showed the positive interaction and binding between $\mathrm{RnC}$ and $\alpha$-glucosidase by hydrogen and hydrophobic bonding [65]. In addition, the rhinacanthin rich extract and $\mathrm{RnC}$ also exhibit anti-adipogenetic activity, suggesting that it can also be used effectively against obesity associated-type II diabetes [66]. 
One of the complex events leading to diabetes is the formation of advanced glycation end products (AGE). AGE's are the products of the Maillard reaction wherein the proteins are glycated when exposed to sugar molecules, as well as from the degradation products of glucose like methylglyoxal, glycolaldehyde, 3-deoxyglucosone and acts as an important biomarker in diabetes. Elevated levels of AGEs are considered as one of the risk factors for the damage occurring to pancreatic beta cells that secrete insulin $[67,68]$. Aqueous extract of $R n$ under in vitro conditions has been reported to significantly trap methylglyoxal, thereby inhibiting the formation of advanced glycation end products in a dose-dependent manner [69]. In silico studies also supported the anti-glycation property of RnC by masking lysine and arginine residues in human serum albumin, thereby preventing glycation [52].

Oxidative stress plays a major role in aggravating the progression of diabetic complications (Figure 2), as the metabolic abnormalities occurring during the process induces the generation of superoxide radicals. This toxic phenomenon further exaggerates the generation of AGE and induces the expression of its receptor [70]. Rhinacanthin-rich extract and $\mathrm{RnC}$ were found to scavenge superoxide free radical in cyclic voltammogram analysis [52]. Additionally, they could also reduce the level of lipid peroxidation and improve the levels of antioxidant enzymes, superoxide dismutase (SOD), catalase (CAT) and glutathione peroxidase (GPx), indicating the effect of the plant in reducing oxidative stress $[10,21]$.

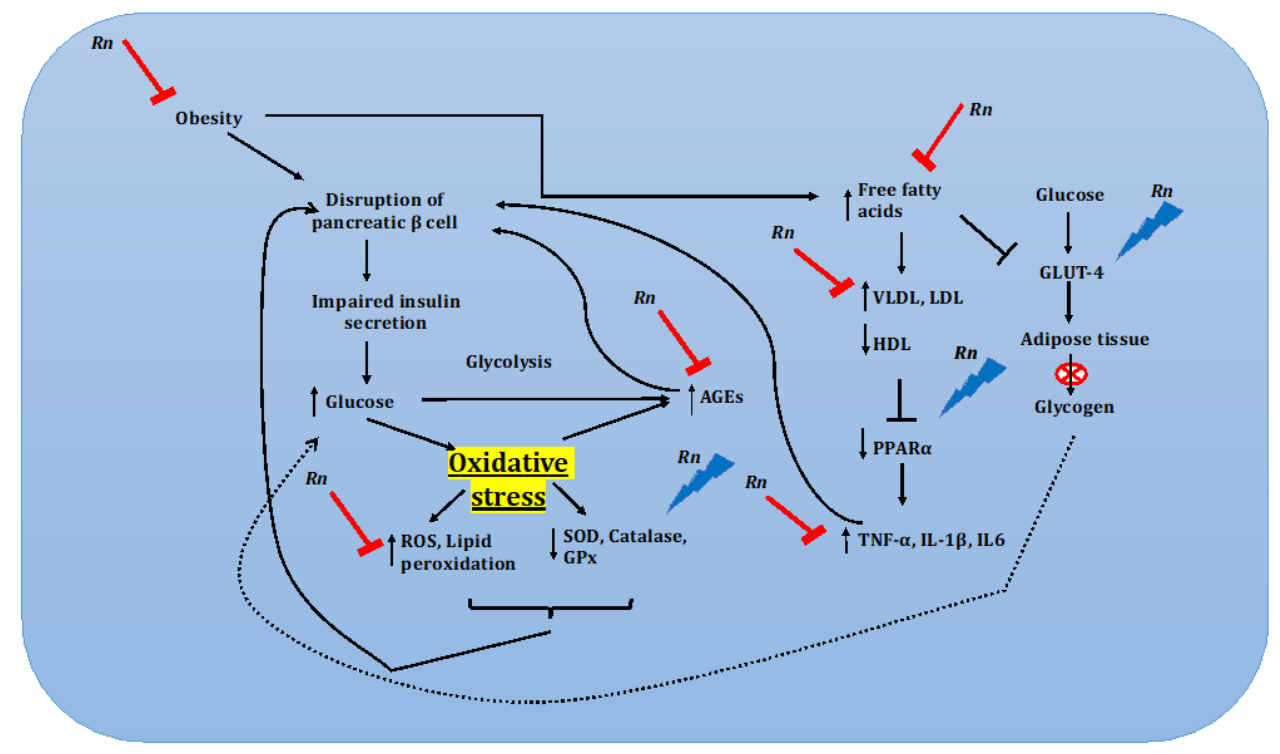

Figure 2. Rhinacanthus nasutus $(R n)$ and its beneficial properties regarding diabetes. $R n$ inhibits the production of Advanced glycation end-product (AGEs), prevents the increase in very low-density lipoprotein (VLDL) and low-density lipoprotein, and prevents the decrease in high density lipoprotein (HDL). $R n$ prevents reactive oxygen species (ROS) damage by activating superoxide dismutase (SOD) catalase and glutathione peroxidase (GPx). $R n$ also regulates peroxisome proliferator-activated receptor $(\mathrm{PPAR} \alpha)$ and glucose transporter type 4 (GLUT-4).

Oral administration of methanol extract of $\mathrm{Rn}$ at $200 \mathrm{mg} / \mathrm{kg}$ body weight in adult male Wistar rats for 30 days reduced the levels of total cholesterol, triglycerides and phospholipids in the liver of diabetic rats to a level like that of non-diabetic control. Further, the extract also reduced the level of low-density lipoprotein-cholesterol (LDL-C) and very-low-density lipoprotein-cholesterol (VLDL-C) in the diabetic rats apart from improving the levels of HDL-C, thereby exhibiting hypolipidemic activity in diabetic rats. More importantly, the plant did not exhibit any hypoglycemic activity in normal rats indicating that it was non-toxic to normal rats [63]. Impaired lipoprotein and lipid metabolism are a characteristic feature of type II diabetes. Pathological changes include increased hepatic secretion and impaired clearance of VLDL [71]. One of the key players in lipid metabolism is insulin, which helps in the storage 
of triacylglycerols (TAG) and reduces the generation of VLDL by declining the level of non-esterified fatty acids in circulation. Similar to $R n$ extract, oral administration of rhinacanthin-rich extract and $\mathrm{RnC}$ significantly normalized the water and food intake in diabetic rats, along with the bodyweight, without causing any significant changes in the normal rats. It also decreased the hyperglycemic levels and destruction of beta cells in the pancreas and increased the serum insulin gradually in diabetic rats. The elevated levels of aspartate aminotransferase (AST) and alanine aminotransferase (ALT) along with blood urea nitrogen (BUN) and creatinine in diabetic rats were significantly reduced by the extract treatment indicating the normalization of the liver as well as kidneys functioning in diabetic rats [72]. Similar results were also reported by Rao et al. 2013, where the key markers of liver functioning were normalized in diabetic rats upon treatment with the plant extract [73]. Further, RnC also modulated the levels of fasting blood glucose (FBG) and glycated hemoglobin $(\mathrm{HbA1c})$ in diabetic rats. $\mathrm{HbA} 1 \mathrm{c}$ is a form of hemoglobin that is in bonding with sugar moiety and is formed when there is an excessive circulation of glucose in the bloodstream. Moreover, $\mathrm{RnC}$ could also reduce the insulin resistance index, modulate antioxidant enzymes, and prevent the shrinking of the islet of Langerhans in diabetic rats [74]. The reported health benefits of the plant extract against diabetic condition could probably be mediated by the activity of cytosolic and mitochondrial enzymes. The level of cytosolic enzymes like glucose-6-phosphate dehydrogenase (G6PDH), glutamate dehydrogenase (GDH) and mitochondrial enzyme succinate dehydrogenase (SDH) is reduced in individuals with diabetes, where G6PDH plays a vital role in antioxidant defense against oxidative stress by the production of NADPH [75] while GDH and SDH are involved in insulin secretion [76,77]. Administration of $R n$ extract significantly restored the levels of these enzymes, thereby ameliorating the diabetic conditions in diabetic rats [73].

Pioneering studies suggest the relationship between chronic inflammation and the pathophysiology of diabetes, and immunomodulatory drugs have been advised in the treatment of individuals with type II diabetes $[78,79]$. Free fatty acids and cholesterol induce inflammation in diabetic individuals and subsequently induces the release of proinflammatory cytokines and chemokines mediated by $\mathrm{NF} \kappa \mathrm{B}[80,81]$. Rhinacanthins-rich extract and RnC administration reduced the levels of free fatty acids and cholesterol, thereby attenuated proinflammatory cytokines TNF- $\alpha$, IL-1 $\beta$, and IL6 in diabetic rats. In addition, the renal concentrations of caspase- 3 and cytochrome $C$ were also reduced in the kidneys of diabetic rats. Diabetes induced histological changes in the kidney such as thickening of the basement membrane of the renal tubules and necrosis of renal tubules were also reduced by the treatment of extract, indicating that the plant extracts can also be used as immunomodulatory agents in alleviating the complications of diabetes [21].

Other than reducing the glucose, triglyceride and cholesterol level, administration of $R n$ can also stimulate the expression of peroxisome proliferator-activated receptor (PPAR $\alpha$ ), fat adiponectin, glucose transporter type 4 (GLUT4) protein expression [82]. Expression of PPAR $\alpha$ and GLUT4 are highly downregulated in individuals affected with diabetes, and both play a major role in the regulation of glucose, lipid metabolism and transports glucose from the circulation into insulin-sensitive cells, respectively $[83,84]$. PPAR agonists were also found to improve against insulin resistance and to reduce the level of TG and glucose [85]. The stimulation of these vital proteins upon Rn extract administration could be the reason behind its antidiabetic effect. Further, the pharmacokinetic and toxicity profile of $\mathrm{RnC}$ by in silico approach suggests that the phytochemical is devoid of carcinogenicity, mutagenicity and non-toxic, suggesting it is safe to use as an antidiabetic drug [72].

\section{Antibacterial, Anti-Fungal, and Anti-Viral Activities of Rhinacanthus nasutus}

Since the discovery of penicillin and its derivatives nearly a century ago, the world's population has grown, and deaths caused by bacterial infections has fallen dramatically. However, in recent years inappropriate and overuse has resulted in the emergence of antibiotic-resistant strains of bacteria, resulting in the need to find novel antibiotics. Extracts of $R n$ have been tested against a range of bacterial strains, and it has been shown to have effective antibiotic activities against Gram-positive strains, including Bacillus cereus, Bacillus globigii, Bacillus subtilis, and Staphylococcus aureus. However, 
it was not effective against Gram-negative strains such as Salmonella typhi, Pseudomonas aeruginosa or Escherichia coli [86], presumably due to the difference in the cell wall made up of Gram-positive and negative bacteria. The rhinacanthin-rich ethanol extract of $R n$ leaves has been shown to have activity against the ulcer and cancer-causing Gram-negative bacteria, Helicobacter pylori, with a minimum inhibitory concentration $\left(\mathrm{MIC}_{50}\right)$ of $0.5 \mathrm{mg} / \mathrm{mL}$ [4]. Further studies have been carried out on RnC extracted from $R n$, showing that the $\mathrm{MIC}_{50}$ for RnC against S. mutans, P. acnes, S. aureus and S. epidermidis are two, eight, two and eight $\mu \mathrm{g} / \mathrm{mL}$, respectively [4]. Studies, including $\mathrm{RnN}$ and $\mathrm{RnQ}$, showed that the $\mathrm{MIC}_{50}$ ranged from 4.9 to $19.53 \mu \mathrm{g} / \mathrm{mL}$ for Gram-positive bacteria but had no anti-biotic effects on Gram-negative bacteria. Interestingly $\mathrm{RnN}$ was shown to be more potent than gentamycin in the inhibition of the Gram-positive bacteria [87].

Traditionally the extracts from $R n$ have been used for the treatment of skin infections with fungi, such as ringworm and tinea cruris [88]. $R n$ has been shown to be effective against a range of clinically relevant fungi, including C. albicans (of the most common hospital-acquired infections), T. mentagrophytes (a common cause of ringworm), C. tropicalis (a common cause of oral thrush, and particular risk to HIV patients) and C. parapsilosis (Cause of endocarditis in patients with prosthetic valves) [86].

Post-2019 and the Severe acute respiratory syndrome coronavirus 2 (SARS-CoV-2) pandemic that has spread around the world at an alarming rate, it has become clear that there is a need for new and effective antiviral drugs. $R n$ and its constitutive compounds have been shown to be effective against various viruses, including Herpes [22,89,90] and Influenza [23]. Recent research has shown that compounds isolated from the aerial parts of $R n$ have neuraminidase inhibitory activity. Neuraminidase is a target on the surface of the influenza virus that plays an important role in the entry of the virus into the cell. It has been postulated that neuraminidase inhibitors may be of benefit in the treatment of SARS-CoV-2 [91]. However, any $R n$ compound would still need to be tested clinically, and there are already several neuraminidase inhibitors that have been tested for safety and would be ahead of any $R n$ compound with regards to clinical testing against SARS-CoV-2.

\section{Conclusions}

$R n$ is a medicinal herb that contains several compounds that are potentially useful medically. $\mathrm{RnC}$ is of interest, particularly in the treatment of diabetes and neurodegeneration, where preclinical studies have shown it to be effective in controlling diabetes by inhibiting $\alpha$-glucosidase and preventing neurodegeneration caused by A $\beta$. There is strong evidence for the effectiveness of $\mathrm{RnC}$ for it to be entered in clinical trials for diabetes and dementia. Other compounds extracted from $R n$ appear to be effective against cancer cell lines. Although these studies are less advanced and the mechanisms yet to be fully understood, there is still potential for $R n$ in cancer treatment.

Funding: The APC was funded by Chulalongkorn University.

Acknowledgments: J.M.B. and M.I.P. were funded by the Rachadapisek Sompote Fund for Postdoctoral Fellowship, Chulalongkorn University. D.S.M. was funded by The Second Century Fund (C2F) for Postdoctoral Fellowship, Chulalongkorn University.

Conflicts of Interest: The authors declare no conflict of interest.

\section{References}

1. Bukke, S.; Raghu, P.S.; Sailaja, G.; Kedam, T.R. The study on morphological, phytochemical and pharmacological aspects of Rhinacanthus nasutus. (L) kurz (A review). J. Appl. Pharm. Sci. 2011, 1, $26-32$.

2. Devanarayana, A.; ERHSS, E.; SSSBDP, S.; Karunarathna, N. Therapeutic usages of Rhinacanthus nasutus (L) kurz (aniththa) in Sri Lankan traditional medicine. Unique J. Ayurvedic Herb. Med. 2015, 3, 10-15.

3. Quattrocchi, U. CRC World Dictionary of Medicinal and Poisonous Plants: Common Names, Scientific Names, Eponyms, Synonyms, and Etymology; CRC Press: Boca Raton, FL, USA, 2012. 
4. Puttarak, P.; Charoonratana, T.; Panichayupakaranant, P. Antimicrobial activity and stability of rhinacanthins-rich Rhinacanthus nasutus extract. Phytomed. Int. J. Phytother. Phytopharm. 2010, 17, 323-327. [CrossRef]

5. Darah, I.; Jain, K. Efficacy of the Rhinacanthus nasutus Nees leaf extract on dermatophytes with special reference to Trichophyton mentagrophytes var. Mentagrophytes and Microsporum canis. Nat. Prod. Sci. 2001, 7, 114-119.

6. Pushpalatha, E.; Muthukrishnan, J. Efficacy of two tropical plant extracts for the control of mosquitoes. J. Appl. Entomol. 1999, 123, 369-373. [CrossRef]

7. Komalamisra, N.; Trongtokit, Y.; Rongsriyam, Y.; Apiwathnasorn, C. Screening for larvicidal activity in some Thai plants against four mosquito vector species. Southeast Asian J. Trop. Med. Public Health 2005, 36, 1412.

8. Rongsriyam, Y.; Trongtokit, Y.; Komalamisra, N.; Sinchaipanich, N.; Apiwathnasorn, C.; Mitrejet, A. Formulation of tablets from the crude extract of Rhinacanthus nasutus (Thai local plant) against Aedes aegypti and Culex quinquefasciatus larvae: A preliminary study. Southeast Asian J. Trop. Med. Public Health 2006, 37, 265-271.

9. Rao, P.V.; Naidu, M.D. Anti diabetic effect of Rhinacanthus nasutus leaf extract in streptozotocin induced diabetic rats. Libyan Agric. Res. Center J. 2010, 1, 310-312.

10. Rao, P.V.; Sujana, P.; Vijayakanth, T.; Naidu, M.D. Rhinacanthus nasutus-Its protective role in oxidative stress and antioxidant status in streptozotocin induced diabetic rats. Asian Pac. J. Trop. Dis. 2012, 2, 327-330. [CrossRef]

11. Horii, H.; Ueda, J.-Y.; Tamura, M.; Sakagami, H.; Tomomura, M.; Tomomura, A.; Shirataki, Y. New biological activity of Rhinacanthus nasutus extracts. In Vivo 2011, 25, 367-373.

12. Shyamal, S.; Latha, P.G.; Suja, S.R.; Shine, V.J.; Anuja, G.I.; Sini, S.; Pradeep, S.; Shikha, P.; Rajasekharan, S. Hepatoprotective effect of three herbal extracts on aflatoxin B1-intoxicated rat liver. Singap. Med. J. 2010, 51, 326-331.

13. Brimson, J.M.; Tencomnao, A.P.T.; Tencomnao, T. Rhinacanthus nasutus protects cultured neuronal cells against hypoxia induced cell death. Molecules 2011, 16, 6322-6338. [CrossRef] [PubMed]

14. Brimson, J.M.; Brimson, S.J.; Brimson, C.A.; Rakkhitawatthana, V.; Tencomnao, T. Rhinacanthus nasutus Extracts Prevent Glutamate and Amyloid- $\beta$ Neurotoxicity in HT-22 Mouse Hippocampal Cells: Possible Active Compounds Include Lupeol, Stigmasterol and $\beta$-Sitosterol. Int. J. Mol. Sci. 2012, 13, 5074-5097. [CrossRef] [PubMed]

15. The Plant List. Available online: http://www.theplantlist.org (accessed on 1 October 2020).

16. Kodama, O.; Ichikawa, H.; Akatsuka, T.; Santisopasri, V.; Kato, A.; Hayashi, Y. Isolation and identification of an antifungal naphthopyran derivative from Rhinacanthus nasutus. J. Nat. Prod. 1993, 56, 292-294. [CrossRef]

17. Wu, T.S.; Hsu, H.C.; Wu, P.L.; Leu, Y.L.; Chan, Y.Y.; Chern, C.Y.; Yeh, M.Y.; Tien, H.J. Naphthoquinone esters from the root of Rhinacanthus nasutus. Chem. Pharm. Bull. 1998, 46, 413-418. [CrossRef]

18. Wu, T.S.; Hsu, H.C.; Wu, P.L.; Teng, C.M.; Wu, Y.C. Rhinacanthin-Q, a naphthoquinone from Rhinacanthus nasutus and its biological activity. Phytochemistry 1998, 49, 2001-2003. [CrossRef]

19. Su, T.-P.; Wu, X.Z.; Cone, E.J.; Shukla, K.; Gund, T.M.; Dodge, A.L.; Parish, D.W. Sigma compounds derived from phencyclidine: Identification of PRE-084, a new, selective sigma ligand. J. Pharmacol. Exp. Ther. 1991, 259, 543-550.

20. Boonyaketgoson, S.; Rukachaisirikul, V.; Phongpaichit, S.; Trisuwan, K. Naphthoquinones from the leaves of Rhinacanthus nasutus having acetylcholinesterase inhibitory and cytotoxic activities. Fitoterapia 2018, 124, 206-210. [CrossRef]

21. Zhao, L.L.; Makinde, E.A.; Shah, M.A.; Olatunji, O.J.; Panichayupakaranant, P. Rhinacanthins-rich extract and rhinacanthin $\mathrm{C}$ ameliorate oxidative stress and inflammation in streptozotocin-nicotinamide-induced diabetic nephropathy. J. Food Biochem. 2019, 43, e12812. [CrossRef]

22. Sendl, A.; Chen, J.L.; Jolad, S.D.; Stoddart, C.; Rozhon, E.; Kernan, M.; Nanakorn, W.; Balick, M. Two new naphthoquinones with antiviral activity from Rhinacanthus nasutus. J. Nat. Prod. 1996, 59, 808-811. [CrossRef]

23. Kernan, M.R.; Sendl, A.; Chen, J.L.; Jolad, S.D.; Blanc, P.; Murphy, J.T.; Stoddart, C.A.; Nanakorn, W.; Balick, M.J.; Rozhon, E.J. Two new lignans with activity against influenza virus from the medicinal plant Rhinacanthus nasutus. J. Nat. Prod. 1997, 60, 635-637. [CrossRef] [PubMed] 
24. Ngoc, T.M.; Phuong, N.T.T.; Khoi, N.M.; Park, S.J.; Kwak, H.J.; Nhiem, N.X.; Trang, B.T.T.; Tai, B.H.; Song, J.H.; Ko, H.J.; et al. A new naphthoquinone analogue and antiviral constituents from the root of Rhinacanthus nasutus. Nat. Prod. Res. 2019, 33, 360-366. [CrossRef] [PubMed]

25. Kwak, H.J.; Park, S.J.; Kim, N.; Yoo, G.; Park, J.H.; Oh, Y.; Nhiem, N.X.; Kim, S.H. Neuraminidase inhibitory activity by compounds isolated from aerial parts of Rhinacanthus nasutus. Nat. Prod. Res. 2018, 32, 2111-2115. [CrossRef] [PubMed]

26. Cohen, G.M.; Stubberfield, C.R. Pyridine nucleotide changes in hepatocytes exposed to quinones. Free Radic. Res. Commun. 1990, 8, 355-363. [CrossRef] [PubMed]

27. Kongkathip, N.; Kongkathip, B.; Siripong, P.; Sangma, C.; Luangkamin, S.; Niyomdecha, M.; Pattanapa, S.; Piyaviriyagul, S.; Kongsaeree, P. Potent antitumor activity of synthetic 1,2-naphthoquinones and 1,4-naphthoquinones. Bioorg. Med. Chem. 2003, 11, 3179-3191. [CrossRef]

28. Maarisit, W.; Yamazaki, H.; Abdjul, D.B.; Takahashi, O.; Kirikoshi, R.; Namikoshi, M. A new pyranonaphtoquinone derivative, 4-oxo-rhinacanthin a, from roots of Indonesian Rhinacanthus nasutus. Chem. Pharm. Bull. 2017, 65, 586-588. [CrossRef]

29. Pethuan, S.; Duangkaew, P.; Sarapusit, S.; Srisook, E.; Rongnoparut, P. Inhibition against mosquito cytochrome P450 enzymes by rhinacanthin-A, -B, and -C elicits synergism on cypermethrin cytotoxicity in Spodoptera frugiperda cells. J. Med. Entomol. 2012, 49, 993-1000. [CrossRef] [PubMed]

30. Chuang, K.A.; Li, M.H.; Lin, N.H.; Chang, C.H.; Lu, I.H.; Pan, I.H.; Takahashi, T.; Perng, M.D.; Wen, S.F. Rhinacanthin C Alleviates Amyloid- $\beta$ Fibrils' Toxicity on Neurons and Attenuates Neuroinflammation Triggered by LPS, Amyloid- $\beta$, and Interferon- $\gamma$ in Glial Cells. Oxid. Med. Cell Longev. 2017, 2017, 5414297. [CrossRef] [PubMed]

31. Chang, C.Z.; Wu, S.C.; Kwan, A.L.; Lin, C.L. Rhinacanthin-C, A Fat-Soluble Extract from Rhinacanthus nasutus, Modulates High-Mobility Group Box 1-Related Neuro-Inflammation and Subarachnoid Hemorrhage-Induced Brain Apoptosis in a Rat Model. World Neurosurg. 2016, 86, 349-360. [CrossRef]

32. Boueroy, P.; Saensa-Ard, S.; Siripong, P.; Kanthawong, S.; Hahnvajanawong, C. Rhinacanthin-C extracted from Rhinacanthus nasutus (L.) inhibits cholangiocarcinoma cell migration and invasion by decreasing MMP-2, uPA, FAK and MAPK pathways. Asian Pac. J. Cancer Prev. 2018, 19, 3605. [CrossRef]

33. Kongkathip, N.; Luangkamin, S.; Kongkathip, B.; Sangma, C.; Grigg, R.; Kongsaeree, P.; Prabpai, S.; Pradidphol, N.; Piyaviriyagul, S.; Siripong, P. Synthesis of novel rhinacanthins and related anticancer naphthoquinone esters. J. Med. Chem. 2004, 47, 4427-4438. [CrossRef] [PubMed]

34. Siripong, P.; Yahuafai, J.; Shimizu, K. Induction of apoptosis in tumor cells by three naphthoquinone esters isolated from Thai medicinal plant: Rhinacanthus nasutus KURZ. Biol. Pharm. Bull. 2006, 29, 2070-2076. [CrossRef] [PubMed]

35. Siripong, P.; Yahuafai, J.; Piyaviriyakul, S.; Kanokmedhakul, K.; Koide, H.; Ishii, T.; Shimizu, K.; Ruchirawat, S.; Oku, N. Inhibitory effect of liposomal rhinacanthin-N isolated from Rhinacanthus nasutus on pulmonary metastasis in mice. Biol. Pharm. Bull. 2012, 35, 1197-1200. [CrossRef] [PubMed]

36. Siripong, P.; Yahuafai, J.; Shimizu, K.; Ichikawa, K.; Yonezawa, S.; Asai, T.; Kanokmedakul, K.; Ruchirawat, S.; $\mathrm{Oku}, \mathrm{N}$. Antitumor activity of liposomal naphthoquinone esters isolated from Thai medicinal plant: Rhinacanthus nasutus KURZ. Biol. Pharm. Bull. 2006, 29, 2279-2283. [CrossRef] [PubMed]

37. Mansoor, T.A.; Ramalho, R.M.; Rodrigues, C.M.P.; Ferreira, M.-J.U. Dibenzylbutane- and butyrolactone-type lignans as apoptosis inducers in human hepatoma HuH-7 cells. Phytother. Res. 2012, 26, 692-696. [CrossRef] [PubMed]

38. Duarte, N.; Lage, H.; Abrantes, M.; Ferreira, M.J. Phenolic compounds as selective antineoplasic agents against multidrug-resistant human cancer cells. Planta Med. 2010, 76, 975-980. [CrossRef]

39. Siripong, P.; Hahnvajanawong, C.; Yahuafai, J.; Piyaviriyakul, S.; Kanokmedhakul, K.; Kongkathip, N.; Ruchirawat, S.; Oku, N. Induction of apoptosis by rhinacanthone isolated from Rhinacanthus nasutus roots in human cervical carcinoma cells. Biol. Pharm. Bull. 2009, 32, 1251-1260. [CrossRef]

40. Thirumurugan, R.S.; Kavimani, S.; Srivastava, R.S. Antitumour activity of rhinacanthone against Dalton's ascitic lymphoma. Biol. Pharm. Bull. 2000, 23, 1438-1440. [CrossRef]

41. Prince, M.J.; Prina, M.; Guerchet, M. World Alzheimer Report 2013-Journey of Caring: An Analysis of Long-Term Care for Dementia; Alzheimer's Disease International: London, UK, 2013; pp. 1-8.

42. Tysnes, O.B.; Storstein, A. Epidemiology of Parkinson's disease. J. Neural Transm. 2017, 124, 901-905. [CrossRef] 
43. Dorsey, R.E.; Elbaz, A.; Nichols, E.; Abd-Allah, F.; Abdelalim, A.; Adsuar, J.C.; Ansha, M.G.; Brayne, C.; Choi, J.Y.J.; Collado-Mateo, D.; et al. Global, regional, and national burden of Parkinson's disease, 1990-2016: A systematic analysis for the Global Burden of Disease Study 2016. Lancet Neurol. 2018, 17, 939-953. [CrossRef]

44. Felsenstein, K.M.; Candelario, K.M.; Steindler, D.A.; Borchelt, D.R. Regenerative medicine in Alzheimer's disease. Transl. Res. 2014, 163, 432-438. [CrossRef] [PubMed]

45. Zhang, C.; Browne, A.; Child, D.; Tanzi, R.E. Curcumin decreases amyloid- $\beta$ peptide levels by attenuating the maturation of amyloid- $\beta$ precursor protein. J. Biol. Chem. 2010, 285, 28472-28480. [CrossRef] [PubMed]

46. Wansawat, S.; Tencomnao, T.; Prasanth, M.I.; Isidoro, C. Mucuna pruriens seed extract promotes neurite outgrowth via ten-4 dependent and independent mechanisms in Neuro2a cells. Sains Malays. 2018, 47, 3009-3015. [CrossRef]

47. Brimson, J.M.; Prasanth, M.I.; Plaingam, W.; Tencomnao, T. Bacopa monnieri (L.) wettst. Extract protects against glutamate toxicity and increases the longevity of Caenorhabditis elegans. J. Tradit. Complement. Med. 2020, 10, 460-470. [CrossRef] [PubMed]

48. Brimson, J.M.; Tencomnao, T. Medicinal herbs and antioxidants: Potential of Rhinacanthus nasutus for disease treatment? Phytochem. Rev. 2013, 13, 643-651. [CrossRef]

49. Brimson, J.M.; Tencomnao, T. Rhinacanthus nasutus Extract as a Neuroprotectant; Elsevier: London, UK, 2015; pp. 77-84.

50. Maheshu, V.; Mahalingam, J.; Teepica, D.; Darsini, P.; Bell, G.S. In Vitro Antioxidant Activity and Polyphenolic Contents of Rauvolfia tetraphylla L., Rhinacanthus nasutus Kurz. and Solena amplexicaulis (Lam.). Int. J. Biomed. Pharm. Sci. 2010, 4, 81-86.

51. Chonthida, T.; Kanjana, P.; Maitree, S.; Somdet, S. Anti-oxidant properties and anti-hemolytic activity of Psidium guajava, Pandanous odorus and Rhinacanthus nasutus. J. Med. Plant Res. 2013, 7, 2001-2009. [CrossRef]

52. Shah, M.A.; Muhammad, H.; Mehmood, Y.; Khalil, R.; Ul-Haq, Z.; Panichayupakaranant, P. Superoxide scavenging and antiglycation activity of rhinacanthins-rich extract obtained from the leaves of Rhinacanthus nasutus. Pharmacogn. Mag. 2017, 13, 652.

53. Heneka, M.T.; Carson, M.J.; Khoury, J.E.; Landreth, G.E.; Brosseron, F.; Feinstein, D.L.; Jacobs, A.H.; Wyss-Coray, T.; Vitorica, J.; Ransohoff, R.M.; et al. Neuroinflammation in Alzheimer's disease. Lancet Neurol. 2015, 14, 388-405. [CrossRef]

54. Hirsch, E.C.; Vyas, S.; Hunot, S. Neuroinflammation in Parkinson's disease. Parkinsonism Relat. Disord. 2012, 18, 210-212. [CrossRef]

55. Ellwardt, E.; Zipp, F. Molecular mechanisms linking neuroinflammation and neurodegeneration in MS. Exp. Neurol. 2014, 262, 8-17. [CrossRef] [PubMed]

56. Hooten, K.G.; Beers, D.R.; Zhao, W.; Appel, S.H. Protective and Toxic Neuroinflammation in Amyotrophic Lateral Sclerosis. Neurotherapeutics 2015, 12, 364-375. [CrossRef] [PubMed]

57. Liu, W.N.; Yan, M.; Chan, A.M. A thirty-year quest for a role of R-Ras in cancer: From an oncogene to a multitasking GTPase. Cancer Lett. 2017, 403, 59-65. [CrossRef] [PubMed]

58. Shostak, K.; Chariot, A. EGFR and NF-kB: Partners in cancer. Trends Mol. Med. 2015, 21, 385-393. [CrossRef] [PubMed]

59. Dang, C.V.; O’Donnell, K.A.; Zeller, K.I.; Nguyen, T.; Osthus, R.C.; Li, F. The c-Myc target gene network. Semin. Cancer Biol. 2006, 16, 253-264. [CrossRef] [PubMed]

60. Hollstein, M.; Sidransky, D.; Vogelstein, B.; Harris, C.C. p53 mutations in human cancers. Science 1991, 253, 49-53. [CrossRef]

61. Siripong, P.; Kanokmedakul, K.; Piyaviriyagul, S.; Yahuafai, J.; Chanpai, R.; Ruchirawat, S.; Oku, N. Antiproliferative naphthoquinone esters from Rhinacanthus nasutus Kurz. roots on various cancer cells. J. Tradit. Med. 2006, 23, 166-172.

62. Saeedi, P.; Petersohn, I.; Salpea, P.; Malanda, B.; Karuranga, S.; Unwin, N.; Colagiuri, S.; Guariguata, L.; Motala, A.A.; Ogurtsova, K. Global and regional diabetes prevalence estimates for 2019 and projections for 2030 and 2045: Results from the International Diabetes Federation Diabetes Atlas. Diabetes Res. Clin. Pract. 2019, 157, 107843. [CrossRef]

63. Rao, P.V.; Madhavi, K.; Naidu, M.D. Hypolipidemic properties of Rhinacanthus nasutus in streptozotocin induced diabetic rats. J. Pharmacol. Toxicol. 2011, 6, 589-595. [CrossRef] 
64. Van De Laar, F.A.; Lucassen, P.L.; Akkermans, R.P.; Van De Lisdonk, E.H.; Rutten, G.E.; Van Weel, C. $\alpha$-Glucosidase inhibitors for patients with type 2 diabetes: Results from a Cochrane systematic review and meta-analysis. Diabetes Care 2005, 28, 154-163. [CrossRef]

65. Shah, M.A.; Khalil, R.; Ul-Haq, Z.; Panichayupakaranant, P. $\alpha$-Glucosidase inhibitory effect of rhinacanthins-rich extract from Rhinacanthus nasutus leaf and synergistic effect in combination with acarbose. J. Funct. Foods 2017, 36, 325-331. [CrossRef]

66. Shah, M.A.; Jakkawanpitak, C.; Sermwittayawong, D.; Panichayupakaranant, P. Rhinacanthins-rich extract enhances glucose uptake and inhibits adipogenesis in 3T3-L1 adipocytes and L6 myotubes. Pharmacogn. Mag. 2017, 13, S817.

67. Ahmed, N. Advanced glycation endproducts-Role in pathology of diabetic complications. Diabetes Res. Clin. Pract. 2005, 67, 3-21. [CrossRef] [PubMed]

68. Singh, V.P.; Bali, A.; Singh, N.; Jaggi, A.S. Advanced glycation end products and diabetic complications. Korean J. Physiol. Pharmacol. 2014, 18,1-14. [CrossRef]

69. Sompong, W.; Adisakwattana, S. Inhibitory effect of herbal medicines and their trapping abilities against methylglyoxal-derived advanced glycation end-products. BMC Complement. Altern. Med. 2015, 15, 1-8. [CrossRef]

70. Giacco, F.; Brownlee, M. Oxidative stress and diabetic complications. Circ. Res. 2010, 107, 1058-1070. [CrossRef]

71. Krauss, R.M. Atherogenicity of triglyceride-rich lipoproteins. Am. J. Cardiol. 1998, 81, 13B-17B. [CrossRef]

72. Shah, M.A.; Reanmongkol, W.; Radenahmad, N.; Khalil, R.; Ul-Haq, Z.; Panichayupakaranant, P. Anti-hyperglycemic and anti-hyperlipidemic effects of rhinacanthins-rich extract from Rhinacanthus nasutus leaves in nicotinamide-streptozotocin induced diabetic rats. Biomed. Pharmacother. 2019, 113, 108702. [CrossRef]

73. Rao, P.; Madhavi, K.; Dhananjaya Naidu, M.; Gan, S.H. Rhinacanthus nasutus Ameliorates Cytosolic and Mitochondrial Enzyme Levels in Streptozotocin-Induced Diabetic Rats. Evid. Based Complementary Altern. Med. 2013, 2013, 486047. [CrossRef]

74. Adam, S.H.; Giribabu, N.; Rao, P.V.; Sayem, A.S.M.; Arya, A.; Panichayupakaranant, P.; Korla, P.K.; Salleh, N. Rhinacanthin C ameliorates hyperglycaemia, hyperlipidemia and pancreatic destruction in streptozotocin-nicotinamide induced adult male diabetic rats. Eur. J. Pharmacol. 2016, 771, 173-190. [CrossRef]

75. Frederiks, W.M.; Bosch, K.S.; De Jong, J.S.; Van Noorden, C.J. Post-translational regulation of glucose-6-phosphate dehydrogenase activity in (pre) neoplastic lesions in rat liver. J. Histochem. Cytochem. 2003, 51, 105-112. [CrossRef] [PubMed]

76. Sener, A.; Malaisse-Lagae, F.; Malaisse, W.J. Stimulation of pancreatic islet metabolism and insulin release by a nonmetabolizable amino acid. Proc. Natl. Acad. Sci. USA 1981, 78, 5460-5464. [CrossRef] [PubMed]

77. Edalat, A.; Schulte-Mecklenbeck, P.; Bauer, C.; Undank, S.; Krippeit-Drews, P.; Drews, G.; Düfer, M. Mitochondrial succinate dehydrogenase is involved in stimulus-secretion coupling and endogenous ROS formation in murine beta cells. Diabetologia 2015, 58, 1532-1541. [CrossRef] [PubMed]

78. Hotamisligil, G.S.; Shargill, N.S.; Spiegelman, B.M. Adipose expression of tumor necrosis factor-alpha: Direct role in obesity-linked insulin resistance. Science 1993, 259, 87-91. [CrossRef] [PubMed]

79. Maedler, K.; Sergeev, P.; Ris, F.; Oberholzer, J.; Joller-Jemelka, H.I.; Spinas, G.A.; Kaiser, N.; Halban, P.A.; Donath, M.Y. Glucose-induced $\beta$ cell production of IL-1 $\beta$ contributes to glucotoxicity in human pancreatic islets. J. Clin. Investig. 2002, 110, 851-860. [CrossRef]

80. Nguyen, M.A.; Favelyukis, S.; Nguyen, A.-K.; Reichart, D.; Scott, P.A.; Jenn, A.; Liu-Bryan, R.; Glass, C.K.; Neels, J.G.; Olefsky, J.M. A subpopulation of macrophages infiltrates hypertrophic adipose tissue and is activated by free fatty acids via Toll-like receptors 2 and 4 and JNK-dependent pathways. J. Biol. Chem. 2007, 282, 35279-35292. [CrossRef]

81. Vandanmagsar, B.; Youm, Y.-H.; Ravussin, A.; Galgani, J.E.; Stadler, K.; Mynatt, R.L.; Ravussin, E.; Stephens, J.M.; Dixit, V.D. The NLRP3 inflammasome instigates obesity-induced inflammation and insulin resistance. Nat. Med. 2011, 17, 179. [CrossRef]

82. Wannasiri, S.; Piyabhan, P.; Naowaboot, J. Rhinacanthus nasutus leaf improves metabolic abnormalities in high-fat diet-induced obese mice. Asian Pac. J. Trop. Biomed. 2016, 6, 1-7. [CrossRef] 
83. Bradford, B.L. PPAR $\gamma$ : An essential regulator of adipogenesis and modulator of fat cell function. Cell 1999, 99, 239-242.

84. Chang, L.; Chiang, S.-H.; Saltiel, A.R. Insulin signaling and the regulation of glucose transport. Mol. Med. 2004, 10, 65-71. [CrossRef]

85. Yamauchi, T.; Kamon, J.; Waki, H.; Murakami, K.; Motojima, K.; Komeda, K.; Ide, T.; Kubota, N.; Terauchi, Y.; Tobe, K. The mechanisms by which both heterozygous peroxisome proliferator-activated receptor $\gamma(\operatorname{PPAR} \gamma)$ deficiency and PPAR $\gamma$ agonist improve insulin resistance. J. Biol. Chem. 2001, 276, 41245-41254. [CrossRef] [PubMed]

86. Sattar, M.A.; Abdullah, N.; Khan, A.H.; Noor, A. Evaluation of anti-fungal and anti-bacterial activity of a local plant Rhinacanthus nasutus (L.). J. Biol. Sci. 2004, 4, 498-500.

87. Siripong, P.; Wongseri, V.; Piyaviriyakul, S.; Yahaufai, J.; Chanpai, R.; Kanakmedakul, K. Antibacterial potential of Rhinacanthus nasutus against clinically isolated bacteria from Thai cancer patients. MU J. Pharm. 2006, 33, 15-22.

88. Ponglux, D. Medicinal Plants; International Congress on Natural Products; Committee: Bangkok, Thailand, 1987.

89. Chaliewchalad, P.; Thongwai, N.; Tragoolpua, Y. Inhibitory effect of Rhinacanthus nasutus (Linn.) Kurz. and Stemona tuberosa (Lour.) extracts on herpes simplex virus infection. J. Med. Plant Res. 2013, 7, 76-84.

90. Thongchuai, B.; Trisuwan, K.; Roytrakul, S.; Tragoolpua, Y.; Sangthong, P. Anti-herpes simplex virus type 2 activity from Rhinacanthus nasutus (Linn.) Kurz. extracts as affected by different extraction solvents. CMUJ. Nat. Sci. 2019, 18, 14-26. [CrossRef]

91. Lu, H. Drug treatment options for the 2019-new coronavirus (2019-nCoV). Biosci. Trends 2020, 14 , 69-71. [CrossRef]

Publisher's Note: MDPI stays neutral with regard to jurisdictional claims in published maps and institutional affiliations. 